\title{
INFLUENCE OF NITRATE SALT SOLUTIONS ON SEED GERMINATION DYNAMICS OF WITHANIA COAGULANS (STOCKS) DUNAL, AN IMPORTANT MEDICINAL PLANT OF THE INDIAN THAR DESERT
}

\author{
Kavita Daiya and Pawan K Kasera* \\ Laboratory of Plant Ecology, Centre of Advanced Study, Department of Botany \\ Jai Narain Vyas University, Jodhpur 342 005, India
}

Keywords: Germination behaviour, Nitrate solutions, Seed morphology, Seedling growth, Withania coagulans

\begin{abstract}
The effect of different concentrations $(0.10,0.25,0.50,0.75$ and $1.0 \%)$ of nitrate salt solutions, viz. $\mathrm{Ca}\left(\mathrm{NO}_{3}\right)_{2}, \mathrm{Co}\left(\mathrm{NO}_{3}\right)_{2}$ and $\mathrm{KNO}_{3}$, on various aspects of fresh and one-year-old seeds and the seedling growth of Withania coagulans (Stocks) Dunal, is a critically endangered medicinal plant of the Indian Thar desert was dealt with. The maximum germination percentage in fresh and one-year-old seeds was observed in 1.0 and $0.10 \% \mathrm{Co}\left(\mathrm{NO}_{3}\right)_{2}$ solutions, respectively. The maximum root: shoot ratio in seedlings from fresh and oneyear-old seeds was observed in 0.75 and $0.50 \%$ of $\mathrm{Ca}\left(\mathrm{NO}_{3}\right)_{2}$ solutions, respectively.
\end{abstract}

The demand for medicinal plants has increased globally due to the resurgence of interest and acceptance of herbal medicine, and is being met largely through collection of these plants from wild populations and the rate of exploitation often exceeds that of the local natural regeneration (Sharma et al. 2006). Thus, there is an urgent need to develop conservation strategies and implement regeneration techniques for the over-exploited medicinal plant species. Seed-based multiplication is the most effective and convenient means for regeneration of most of the desert species.

Withania coagulans (Stocks) Dunal (Solanaceae) is a critically endangered medicinal plant (Jain et al. 2009) and used in the Unani System of medicine as Tukhm-e-Hayath, this small shrub, popularly known as Indian cheese maker, is commercially important for its efficacy in the treatment of ulcers, rheumatism, and dropsy, constipation and sexual debility. The seeds are reported to be sedative, emetic and stomachic, blood purifier and febrifuge, diuretic and bitter tonic in dyspepsia and also promote growth of infants (Hemalatha et al. 2004). In the Indian subcontinent, its berries are used as a blood purifier, twigs are chewed for cleaning of teeth, and smoke of the plant is inhaled for relief in toothache (Gupta 2013). In northern India, traditional healers use its dry fruits for the treatment of diabetes.

Seed germination and seedling vigour are prerequisites for successful establishment of plant stands (Rauf et al. 2007). Seed dormancy is a mechanism by which seeds inhibit their germination and wait for more favourable conditions (Finkelstein et al. 2008), whereas seed germination is a mechanism, in which morphological and physiological alterations result in activation of the embryo. Before germination, seeds absorb water, leading to expansion and elongation of seed embryos (Hermann et al. 2007).

Nitrate can act as a source of $\mathrm{N}$ and enhance seed germination (Atia et al. 2009) by adjusting $\mathrm{K}^{+} / \mathrm{Na}^{+}$ratio and increasing ATP production and seed respiration (Zheng et al. 2009). The present study is focused on morphological parameters of seeds such as shape, size, colour, weight and on

*Author for correspondence: <pkkasera1963@gmail.com>, <jnvupkkasera@yahoo.co.in>. 
the influence of different nitrate salts on seed germination and seedling growth in W. coagulans under controlled laboratory conditions.

The mature fruits of Withania coagulans were purchased from authorized Ayurvedic shop during February - March 2016 and 2017. The seeds were cleaned and stored in plastic containers with parad tablets (a mercury compound) to protect them from insects in the controlled laboratory conditions. Seed morphological characters such as shape, size, colour and weight were recorded, based on the examination of 100 seeds, with the help of dissecting microscope and Vernier calliper. Seed viability was tested by the tetrazolium method, following Porter et al. (1947).

The seeds were first cleaned and treated with $0.1 \% \mathrm{HgCl}_{2}$ for $30 \mathrm{sec}$ and then kept under running tap water for 3 - 4 hrs for removing injurious substances, if any. Different pre-treatments were then provided to fresh as well as one-year-old seeds for enhancing germination percentage and facilitating seedlings growth. Sterilized Petri dishes lined with single layer of filter paper moistened with distilled water were used for conducting experiments to study seed germination in alternate white light (1000 lux) and dark (12 hrs) obtained from 3 fluorescent tubes of 40 Watts each fitted at a height of half meter from Petri dishes in seed germinator at $28^{\circ} \mathrm{C}$ temperature. In each set of three Petri dishes, 10 seeds pre-soaked for 24 hrs with different concentrations $(0.10$, $0.25,0.50,0.75,1.0 \%)$ of $\mathrm{Ca}\left(\mathrm{NO}_{3}\right)_{2}, \mathrm{Co}\left(\mathrm{NO}_{3}\right)_{2}$ and $\mathrm{KNO}_{3}$ were placed in each dish. Distilled water alone was used for the control set. Filter paper was moistened daily with $0.2 \mathrm{ml}$ of distilled water. Observations were recorded daily for 15 days. Germination percentage and the root and shoot length of seedlings were analysed after 15 days. The experiment was repeated for confirming the observations and the data obtained were subjected to ANOVA using RBD, as suggested by Gomez and Gomez (1984).

Study of seed morphology is important to understand its adaptation variability in desert condition (Verma and Kasera 2008). Morphological information on seeds of W. coagulans is presented in Table 1. The seeds were ear-shaped and pale yellow in colour. Their mean length and breadth were $0.349 \pm 0.07$ and $0.307 \pm 0.04 \mathrm{~mm}$, respectively. The weight of 100 seeds was $0.277 \mathrm{~g}$. The fresh and one-year-old seeds showed 93.33 and $63.33 \%$ viability, respectively.

Table 1. Morphological parameters of W. coagulans seeds.

\begin{tabular}{|c|c|}
\hline Parameters & Values \\
\hline Shape & Ear \\
\hline Length (mm) & $0.349 \pm 0.07$ \\
\hline Breadth (mm) & $0.307 \pm 0.04$ \\
\hline Colour & Pale yellow \\
\hline Weight of 100 seeds (g) & 0.277 \\
\hline \multirow{2}{*}{$\begin{array}{l}\text { Viability } \\
(\%)\end{array}$} & 93.33 \\
\hline & 63.33 \\
\hline
\end{tabular}

In most of the desert plant species germination process can be enhanced to some extent by appropriate pre-treatment of seeds (Bose and Sharma 2000). Among various chemicals, nitrates play an important role in breaking seed dormancy (Kasera and Sen 1992). Nitrate inhibits seed dormancy by decreasing the levels of ABA in seeds (Finkelstein et al. 2008). The fresh and oneyear-old seeds of $W$. coagulans showed maximum germination percentage i.e. 46.66 and 53.33 with 1.0 and $0.10 \mathrm{Co}\left(\mathrm{NO}_{3}\right)_{2}$ concentrations, respectively (Table 2). Observations of Jayakumar 
et al. (2009) that cobalt at low concentration improves germination find support from the present findings.

Table 2. Effect of different concentrations of nitrate solution pre-treatments on seed germination, seedling growth, root/shoot lengths $(\mathrm{R} / \mathrm{S}$ ratio) in fresh and one-year-old seeds of $W$. coagulans.

\begin{tabular}{|c|c|c|c|c|c|c|c|c|c|}
\hline \multirow{3}{*}{$\begin{array}{l}\text { Nitrate } \\
\text { solutions }\end{array}$} & \multirow{3}{*}{$\begin{array}{l}\text { Conc. } \\
(\%)\end{array}$} & \multirow{2}{*}{\multicolumn{2}{|c|}{$\begin{array}{l}\text { Germination } \\
(\%)\end{array}$}} & \multicolumn{4}{|c|}{ Seedling growth $(\mathrm{cm})$} & \multirow{2}{*}{\multicolumn{2}{|c|}{$\begin{array}{l}\mathrm{R} / \mathrm{S} \\
\text { ratio }\end{array}$}} \\
\hline & & & & & & & & & \\
\hline & & Fresh & Old & Fresh & Old & Fresh & Old & Fresh & Old \\
\hline \multirow{6}{*}{$\mathrm{Ca}\left(\mathrm{NO}_{3}\right)_{2}$} & 0.0 & 3.33 & 10.0 & 1.2 & 0.93 & 2.9 & 2.5 & 0.41 & 0.37 \\
\hline & 0.10 & 23.33 & 6.66 & 1.171 & 1.5 & 2.7 & 3.15 & 0.433 & 0.47 \\
\hline & 0.25 & 6.66 & 3.33 & 1.25 & 1.6 & 1.95 & 0.8 & 0.641 & 2.0 \\
\hline & 0.50 & 23.33 & 16.66 & 1.35 & 1.78 & 2.04 & 2.26 & 0.664 & 2.26 \\
\hline & 0.75 & 3.33 & 30.0 & 1.0 & 1.85 & 3.0 & 2.43 & 3.33 & 0.76 \\
\hline & 1.00 & 10.0 & 36.66 & 0.53 & 1.74 & 1.16 & 2.85 & 0.457 & 0.61 \\
\hline \multirow[t]{2}{*}{$\mathrm{CD}$} & & $1.82^{* *}$ & $\mathrm{~ns}$ & ns & $\mathrm{ns}$ & $1.27^{* *}$ & $1.20^{* *}$ & $0.21^{* *}$ & $0.95^{* *}$ \\
\hline & 0.0 & 3.33 & 10.0 & 1.2 & 0.93 & 2.9 & 2.5 & 0.41 & 0.37 \\
\hline \multirow{5}{*}{$\mathrm{Co}\left(\mathrm{NO}_{3}\right)_{2}$} & 0.10 & 10.0 & 53.33 & 0.366 & 1.08 & 0.966 & 1.92 & 0.378 & 0.56 \\
\hline & 0.25 & 10.0 & 30 & 1.233 & 1.13 & 2.233 & 1.87 & 0.552 & 0.60 \\
\hline & 0.50 & 40.0 & 36.66 & 1.025 & 1.0 & 2.2 & 1.53 & 0.465 & 0.65 \\
\hline & 0.75 & 30.0 & 26.66 & 0.544 & 0.8 & 1.011 & 1.71 & 0.538 & 0.46 \\
\hline & 1.00 & 46.66 & 43.33 & 0.664 & 0.87 & 1.064 & 2.0 & 0.624 & 0.43 \\
\hline \multirow[t]{3}{*}{$\mathrm{CD}$} & & $\mathrm{ns}$ & $\mathrm{ns}$ & $\mathrm{ns}$ & $\mathrm{ns}$ & $\mathrm{ns}$ & $\mathrm{ns}$ & $\mathrm{ns}$ & $0.05^{* *}$ \\
\hline & 0.0 & 3.33 & 10.0 & 1.2 & 0.93 & 2.9 & 2.5 & 0.41 & 0.37 \\
\hline & 0.10 & - & 13.33 & - & 1.0 & - & 2.0 & - & 0.5 \\
\hline \multirow[t]{4}{*}{$\mathrm{KNO}_{3}$} & 0.25 & 3.33 & 6.66 & 0.2 & 2.4 & 0.2 & 1.95 & 1.0 & 1.23 \\
\hline & 0.50 & - & 33.33 & - & 1.41 & - & 2.07 & - & 0.68 \\
\hline & 0.75 & 3.33 & 16.66 & 0.2 & 1.56 & 0.2 & 3.16 & 1.0 & 0.49 \\
\hline & 1.00 & 6.66 & 20.0 & 0.55 & 1.81 & 2.0 & 2.2 & 0.275 & 0.82 \\
\hline $\mathrm{CD}$ & & $2.26^{* *}$ & ns & $0.19^{* *}$ & ns & $1.04^{* * *}$ & ns & ns & $0.21^{* *}$ \\
\hline
\end{tabular}

- = No germination, $\mathrm{ns}=$ Non-significant, and ${ }^{* *}=$ Significant at $(\mathrm{p}<0.01)$.

The maximum length of root $(1.35 \mathrm{~cm})$ and shoot $(3.0 \mathrm{~cm})$ was observed in 0.50 and $0.75 \%$ $\mathrm{Ca}\left(\mathrm{NO}_{3}\right)_{2}$ solutions, respectively in freshly purchased seeds (Table 2 ). In one-year-old seeds, maximum root $(2.4 \mathrm{~cm})$ and shoot $(3.16 \mathrm{~cm})$ lengths were recorded in 0.25 and $0.75 \%$ of $\mathrm{KNO}_{3}$ solutions, respectively (Table 2). The highest R/S (root/shoot) ratio in fresh (3.33) and one-yearold seed (2.26) were observed in 0.75 and $0.50 \% \mathrm{Ca}(\mathrm{NO} 3)_{2}$, respectively (Table 2). Calcium plays an essential role in preserving the structural and functional integrity of cell membrane and stabilizing the cell-wall structure in plants (Rengel 1992, Howladar and Rady 2012). Lal and Kasera (2014) found $\mathrm{Ca}\left(\mathrm{NO}_{3}\right)_{2}$ and $\mathrm{KNO}_{3}$ to be most suitable for optimizing germination and seedling development in Commiphora wightii. Likewise, Cetinbas and Koyuncu (2006) could cause effective germination with treatment of $\mathrm{KNO}_{3}$ in Prunus avium. Swami et al. (2011) 
reported maximum root and shoot lengths in one-year-old seeds of Withania somnifera with treatment of $0.25 \% \mathrm{ZnNO}_{3}$ and $1.0 \% \mathrm{KNO}_{3}$. Gashi et al. (2012) observed maximum germination of Ramonda serbica seeds treated with $\mathrm{KNO}_{3}$.

Statistical analysis has shown that values of shoot length and R/S ratio were significant at $\mathrm{p}<0.01$ for the fresh as well as in one-year-old seeds treated with $\mathrm{Ca}\left(\mathrm{NO}_{3}\right)_{2}$; the same applies to germination percentage of fresh seeds treated with $\mathrm{KNO}_{3}$. Present study reveals that seeds of $W$. coagulans are nitrophilous, showing a remarkable enhancement of germination when pre-treated with various nitrate solutions. Lower concentrations $(0.10 \%)$ of $\mathrm{Co}\left(\mathrm{NO}_{3}\right)_{2}$ promoted the germination in old seeds, while higher ones (1.0\%) in fresh seeds. It may therefore be concluded that $\mathrm{Co}\left(\mathrm{NO}_{3}\right)_{2}$ offers the best treatment for the large-scale multiplication of $W$. coagulans.

\section{Acknowledgements}

The authors are thankful to the Head, Centre of Advanced Study, Department of Botany, J.N. Vyas University, Jodhpur, for providing necessary laboratory facilities. Financial support from the CSIR, New Delhi \{No. 09/098(128)/2015 EMR-1; dated 01.01.2016\} and from the UGC, New Delhi [UGC-(SAP-II)-CAS \{No. F. 5-1/2013 (SAP-II) dated 03.01.2014\}] is gratefully acknowledged.

\section{References}

Atia A, Debez A, Barhoumi Z, Smaoui A and Abdelly C 2009. ABA, GA 3 and nitrate may control seed germination of Crithmum monitimum (Apiaceae) under saline conditions. Com. Rend. Biol. 332: 704710.

Bose B and Sharma MCS 2000. Influence of maize seed treatment with nitrates on nitrogen economy and nitrogen pollution. Indian J. Plant Physiol. 5: 93-95.

Çetinbas M and Koyuncu F 2006. Improving germination of Prunus avium L. seeds by gibberellic acid, potassium nitrate and thiourea. Hort. Sci. 33: 119-123.

Finkelstein R, Reeves W, Ariizumi T and Steber C 2008. Molecular aspects of seed dormancy. Ann. Revu. Plant Biol. 59: 384-415.

Gashi B, Abdullai K, Mata V and Kongjika E 2012. Effect of gibberellic acid and potassium nitrate on seed germination of the resurrection plants Ramonda serbica and Ramonda nathaliae. Afr. J. Biotechnol. 11: 4537-4542.

Gomez KA and Gomez AA 1984. Statistical Procedures for Agricultural Research. (2 ${ }^{\text {nd }}$ Ed.). John Wiley \& Sons, New York, USA. pp. 294.

Gupta PC 2013. Withania coagulans (Stocks) Dunal - An overview. Int. J. Pharma. Sci. Res. 12: 68-71.

Hemalatha S, Wahi AK, Singh PN and Chaurasia JPN 2004. Hypoglycemic activity of Withania coagulans (Stocks) Dunal in Streptozotocin induced diabetic rats. J. Ethno. Pharmacol. 93: 261-264.

Hermann K, Meinhand J, Dobrev P, Linkies A, Pesek B, Heb B, Machackova I, Fischer U and LeubnerMetzger G 2007. 1- Aminocyclopropane-1- carboxylic acid and abscisic acid during the germination of sugarbeet (Beta vulgaris L.) - a comparative study of fruits and seeds. J. Expt. Bot. 58: 3047-3060.

Howladar SM and Rady MM 2012. Effects of calcium paste as a seed coat on growth, yield and enzymatic activities in $\mathrm{NaCl}$ stressed-pea plants. Afr. J. Biotechnol. 11: 14140-14145.

Jain R, Sinha A, Kachhwaha S and Kothari SL 2009. Micropropagation of Withania coagulans (Stocks) Dunal: a critically endangered medicinal herb. J. Plant Biochem. Biotechnol. 18: 249-252.

Jayakumar K, Abdul Jaleel C and Vijayarengan P 2009. Effect of different concentrations of cobalt on pigment contents of soybean. Bot. Res. Intl. 2: 153-156.

Kasera PK and Sen DN 1992. Effect of different nitrates on seed germination of Chenopodium spp. (Linn.). Ann. Arid Zone 31: 75-76. 
Lal H and Kasera PK 2014. Nitrates improved seed germination performance in Commiphora wightii (Guggal), a data deficient medicinal plants from the Indian arid zone. J. Plant Develop. 21: 63-73.

Porter RH, Durell M and Room HJ 1947. The use of 2, 3, 5- triphenyl tetrazolium chloride as a measure of seed germinability. Plant Physiol. 22: 149-159.

Rauf M, Munir M, Ulhassan M, Ahmad M and Afzal M 2007. Performance of wheat genotypes under osmotic stress at germination and early seedling growth. Afr. J. Biotechnol. 6: 971-975.

Rengel Z 1992. The role of calcium in salt toxicity. Plant Cell Environ. 15: 625-632.

Sharma RK, Sharma S and Sharma SS 2006. Seed germination behaviour of some medicinal plants of Lahaul and Spiti cold desert (Himachal Pradesh): Implications for conservation and cultivation. Curr. Sci. 90: 1113-1118.

Swami A, Kasera PK and Sahoo KP 2011. Influence of nitrate salts on seed germination and seedling growth of Withania somnifera (Ashwagandha) from the Indian Thar desert. J. Indian Bot. Soc. 90: 374-377.

Verma V and Kaesra PK 2008. Standardization of seed germination aspects in Asparagus racemosus Willd, and Sida cordifolia Linn. in arid region of India. Seed Res. 36: 176-182.

Zheng C, Jiang D, Liab F, Dai T, Liu W, Jing Q and Cao W 2009. Exogenous nitric oxide improves seed germination in wheat against mitochondrial oxidative damage induced by high salinity. Env. Exp. Bot. 67: $222-227$.

(Manuscript received on 13 September, 2018; revised on 29 December, 2018) 